\title{
DAYA TERIMA KUE BARUAS DENGAN PENAMBAHAN TEPUNG DAUN KELOR TUA
}

\author{
Muh. Hasyim $^{1 凶}$, Hapzah $^{1}$ \\ ${ }^{1}$ Jurusan Gizi Poltekkes Kemenkes Mamuju
}

\section{ARTICLE INFO}

Article history

Submitted : 2019-09-25

Revised : 2019-11-05

Accepted : 2019-12-21

\section{Keywords: \\ Cake baruas \\ Moringa flour \\ Acceptability \\ Nutrients}

\section{Kata Kunci:}

Kue baruas

Tepung kelor

Daya terima

Zat gizi

\begin{abstract}
Moringa leaves is a type of vegetable that is very rich in nutrients, especially $\mathrm{Fe}, \mathrm{Ca}$, $\mathrm{Zn}$, and protein. One of the causes of stunting in young children is the lack of mineral intake The purpose of this study was to determine differences in preferences and nutrient content of new cake by adding different concentrations of Moringa leaf flour. Methods of research Preference Test/Acceptance Test, population 157 people, a sample of 87 people, the sample was selected using a simple random method of 157 populations Statistical test using Kruskal Wallis, and Mann Whitney U test, nutrient analysis, Atomization (AAS) for metals, and kjeldahl for protein. The results of the study, all types of cakes favored by panelists The highest nutrient content was cake adding $15 \%$ Moringa leaf flour. The average score of panelists on the new cake addition of 5\% Moringa leaf flour was 30.2, there were differences in panelist acceptance based on taste and color, p-value 0,000, there were no differences in ratings based on taste and construction p-values 0,271 and 0,061 The results can be summarized again. Conclusions, Nutrients $(\mathrm{Ca}, \mathrm{Fe}, \mathrm{Zn})$ are highest in the fresh moringa $15 \%$, there are panelist differences based on taste and color, no differences based on texture and aroma, the most preferred cake is $5 \%$ new cake. Suggestions, Future research, using a cake addition of 5\% Moringa leaf flour, by improving the color taste with the addition of BTM and natural coloring.
\end{abstract}

Daun kelor merupakan jenis sayuran yang kaya zat gizi terutama, $\mathrm{Fe}, \mathrm{Ca}, \mathrm{Zn}$, dan protein. Salah satu penyebab stunting pada balita adalah kurangnya asupan mineral tersebut. Tujuan dari penelitian ini adalah mengetahui perbedaan kesukaan dan kandungan zat gizi kue baruas dengan penambahan tepung daun kelor konsentrasi berbeda. Metode penelitain Preference Test/Acceptance Test, Populasi 157 orang, sampel sebanyak 87 orang, sampel dipilih menggunakan metode acak sederhana dari 157 populasi. Uji statistic menggunakan Kruskal Wallis, dan uji Mann Whitney U, analisa zat gizi, Atomisasi (AAS) untuk Logam, dan kjeldahl untuk protein. Hasil penelitian, semua jenis kue disukai oleh panelis Kandungan zat gizi tertinggi adalah kue penambahan tepung daun kelor $15 \%$. Rata-rata penilaian panelis terhadap kue baruas penambahan tepung daun kelor 5\% tertinggi sebesar 30,2 ada perbedaan penerimaan panelis berdasarkan rasa dan warna, p-value 0,000 , tidak ada perbedaan penilaian berdasarkan rasa dan aroma $p$-value 0,271 dan 0,061. Kesimpulan, Zat gizi (Ca, Fe, Zn) teringggi pada baruas kelor $15 \%$, ada perbedaan kesukaan panelis berdasarkan rasa dan warna, tidak ada perbedaan berdasarakan tekstur dan aroma, kue yang paling disukai adalah kue baruas 5\%. Saran, Penelitian selanjutnya, mengunakan kue penambahan tepung daun kelor 5\%, dengan memperbaiki rasa warna dengan penambahan BTM dan pewarna alami.

\section{Corresponding Author:}

Muh. Hasyim

Jurusan Gizi Poltekkes Kemenkes Mamuju

Telp. 082271018383

Email: hasyim65.gizi@gmail.com

\section{PENDAHULUAN}

Balita stunting disebabkan oleh rendahnya asupan gizi dan penyakit infeksi berulang. Apabila janin dalam kandungan mendapatkan gizi yang cukup, maka ketika lahir berat dan panjang badannya akan normal.
Periode yang paling kritis dalam penanggulangan stunting dimulai sejak janin dalam kandungan sampai anak berusia 2 tahun yang disebut dengan periode emas (seribu hari pertama kehidupan), oleh karena itu perbaikan gizi diprioritaskan pada usia seribu hari pertama 
kehidupan yaitu 270 hari selama kehamilannya dan 730 hari pada kehidupan pertama bayi yang dilahirkannya.

Asupan zat gizi anak stunting, terutama Protein, $\mathrm{Fe}$ dan $\mathrm{Zn}$ lebih rendah dibandingkan dengan anak tidak stunting. Asupan protein yang rendah, berkorelasi positif dengan kejadian penyakit infeksi pada balita stunting (Adenike \& Engineering, 2014) Balita nonstunting mempunyai asupan energi, protein, zink adekuat yaitu $71,9 \%, 93,7 \%$, dan $71,9 \%$ serta perkembangan sesuai yaitu $75 \%$. Balita stunting mempunyai asupan energi, zink in adekuat yaitu $68,7 \%, 65,6 \%$ dan protein adekuat yaitu $68,7 \%$ serta perkembangan menyimpang yaitu 62,5\% (Adani \& Nindya, 2017). Prevalensi stunting pada kelompok asupan protein rendah, lebih besar 1,87 kali daripada kelompok asupan protein cukup, begitu pula pada asupan kalsium dan fosfor, prevalensi stunting pada kelompok asupan kalsium rendah, lebih besar 3,625 kali daripada kelompok asupan kalsium cukup, dan prevalensi stunting pada kelompok asupan fosfor rendah, lebih besar 2,29 kali daripada kelompok asupan fosfor cukup (Sari, Juffrie, Nurani, \& Sitaresmi, 2016).

Daun kelor (Moringa oleifera) adalah salah satu tanaman yang sangat kaya akan zat gizi, preparasi serbuk daun kelor dengan proses pengeringan dapat mempengaruhi kandungan gizinya, pengeringan dengan menggunakan cahaya matahari dapat menurunkan kandungan mineral daun kelor lebih tinggi dibanding pengeringan pada suhu ruang (Adenike \& Engineering, 2014). Jumlah protein yang mampu dipertahankan dengan pengeringan tanpa matahari adalah sebesar 71,68\%, sedangkan pengeringan dengan matahari hanya mampu mempertahankan protein sebanyak 71,39\%. Umur daun mempengaruhi kandungan zat gizi daun kelor. Penelitian dengan membagi 3 kelompok daun kelor (pucuk, muda, dan tua) dan 3 jenis metode pengeringan, diperoleh bahwa kelompok daun yang kandungan zat gizinya (terutama $\mathrm{Fe}$, dan $\mathrm{Ca}$ ) paling tinggi adalah kelompok daun tua, dengan metode pengeringan hanya dengan menganginanginkan saja, yaitu $\mathrm{Fe}(12,43) \mathrm{mg}$, dan $\mathrm{Ca}$ $(1501,16) \mathrm{mg}$, dua kelompok daun lainnya, lebih rendah dari itu (Salim \& Hasyim, 2016).

Kue baruas adalah salah satu kue tradisional, yang biasa digunakan sebagai hidangan pelengkap minum teh/kopi, Penelitian tentang penambahan/modifikasi terhadap nilai gizi dan daya terima dilaporkan bahwa terdapat perbedaan signifikan nilai gizi pada setiap kelompok produk, demikian juga dengan penlaian panelis tentang perbedaan warna, aroma, tekstur dan rasa pada setiap konsentrasi penambahan produk dengan nilai $\mathrm{p}<0,05$.

\section{METODE PENELITIAN \\ Jenis Penelitian}

Penelitian ini adalah penelitian eksperiment untuk menilai perbedaan kandungan zat gizi dan penilaian panelis terhadap produk baruas dengan penambahan tepung daun kelor tua dengan konsentrasi berbeda $(0 \%, 5 \%, 10 \%$, dan $15 \%)$. Metode yang digunakan adalah uji laboratoriun untuk menilai kandungan zat gizi setiap jenis kue.

\section{Populasi dan Sampel}

Panelis yang digunakan adalah masyarakat yang sangat akrab dengan kue baruas, terdiri dari ibu balita, ibu menyusui, ibu hamil, ibu rumah tangga dan remaja putri.

Jumlah sampel disesuaikan dengan jumlah panelis sebanyak 87 orang, jumlah panelis masyarakat $35-100$ orang, (Ayustaningwarno, 2014). Metode pengambilan sampel simple random sampling. Calon Panel yang bersedia berpartisipasi dan memenuhi kriteria sebanyak 157 orang.

\section{Pengumpulan Data}

Pengujian dilakukan, mendatangi panelis sebanyak 4 kali, untuk menilai 4 jenis sampel. Jumlah panelis 100 orang, 13 panelis memberikan data tidak lengkap.

\section{Analisis Data}

Analisis data menggunakan software komputer. Analisis dilakukan dengan menggunakan uji Kruskal Wallis, dan uji Mann Whitney $U$.

\section{HASIL PENELITIAN}

Zat gizi yang dianalisis adalah yang sangat terkait dengan kejadian stunting, yaitu Protein, Kalsium, Zat Besi, Zink, analisa zat gizi dilakukan di Labkes Kemenkes Makassar, menggunakan metode standar.

Tabel 1. menggambarkan bahwa dari ke empat jenis zat gizi yang dianalisis tertinggi adalah kue dengan penambahan tepung daun kelor konsentrasi tertinggi yaitu $15 \%$. Kadar air paling rendah adalah kue dengan penambahan 
tepung daun kelor 5\%. Daya terima dinilai menggunakan uji hedonic, yaitu menilai tingkat kesukaan panelis berdasarkan rasa, aroma, tekstur dan warna kue. Panelis terdiri dari ibu- ibu yang sangat akrab dengan rasa asli dari kue baruas, terdiri dari ibu hamil, ibu menyusui, ibu balita, ibu rumah tangga, dan wanita dewasa.

Tabel 1. Nilai Gizi Produk berdasarkan Persentase Penambahan Tepung Daun Kelor

\begin{tabular}{lccccc}
\hline \multirow{2}{*}{ Jenis Kue } & \multicolumn{4}{c}{ Kandungan Zat Gizi } & \multirow{2}{*}{ Kadar Air } \\
\cline { 2 - 5 } & Fe (mg) & Ca (mg) & Zn (mg) & Prot $(\mathbf{g r})$ & \\
\hline Baruas Non Kelor & 20.11 & 52.98 & 8.09 & 6.5 & 8.02 \\
Baruas Kelor 5\% & 32.19 & 162.86 & 7.38 & 6.69 & 7.15 \\
Baruas Kelor 10\% & 44.95 & 1042.56 & 9.48 & 7.36 & 8.45 \\
Baruas Kelor 15\% & 50.48 & 1378.27 & 9.83 & 7 & 7.53 \\
\hline
\end{tabular}

Tabel 2. menggambarkan bahwa produk yang paling disukai oleh panelis adalah produk dengan penambahan tepung daun kelor $5 \%$, tabel di atas juga menggambarkan bahwa panelis lebih menyukai produk tanpa penambahan tepung daun kelor. Berdasarkan rasa dan tekstur panelis lebih menyukai produk dengan penambahan tepung daun kelor $5 \%$. Tabel diatas juga menggambarkan bahwa tingkat kesukaan panelis paling rendah adalah produk dengan penambahan tepung daun kelor paling tinggi (15\%). Perbedaan tingkat kesukaan panelis terhadap produk diuji dengan uji statistik.

Tabel 2. Tingkat Kesukaan Panelis terhadap Produk dengan Penambahan Tepung Daun Kelor pada Konsentrasi Berbeda

\begin{tabular}{clccccc}
\hline No & \multicolumn{1}{c}{ Jenis Kue } & Rasa & Aroma & Tekstur & Warna & Jumlah \\
\hline 1. & Baruas Non Kelor & 8.7 & 7.6 & 7.6 & 8.2 & 31.8 \\
2. & Baruas Kelor 5\% & 7.4 & 7.8 & 8.2 & 6.9 & 30.3 \\
3. & Baruas Kelor 10\% & 6.8 & 6.7 & 7.6 & 6.8 & 27.8 \\
4. & Baruas Kelor 15\% & 7.1 & 6.9 & 7.4 & 6.6 & 28 \\
\hline
\end{tabular}

Tabel 3. menggambarkan bahwa ada perbedaan tingkat kesukaan panelis terhadap produk berdasarkan rasa, aroma dan warna. Uji statistic menggunakan Friedman Test diperoleh nilai $\rho$-value $<0,05$, tidak terdapat perbedaan tingkat kesukaan panelis terhadap produk berdasarkan tekstur, nilai $\rho$-value $>0,05$.

Tabel 3. Perbedaan Tingkat Kesukaan Panelis terhadap Produk dengan Penambahan Tepung Daun Kelor pada Konsentrasi Berbeda

\begin{tabular}{lccccc}
\hline & \multicolumn{5}{c}{ Produk Kue Baruas } \\
\cline { 2 - 6 } Uji Hedonik & \multicolumn{5}{c}{ Nilai Rata-Rata } \\
\cline { 2 - 6 } & $\mathbf{0 \%}$ & $\mathbf{5 \%}$ & $\mathbf{1 0 \%}$ & $\mathbf{1 5 \%}$ & $\boldsymbol{\rho}$-Valu $\boldsymbol{*}^{*}$ \\
\hline Rasa & 8.54 & 7.39 & 6.77 & 7.06 & $0.000^{*}$ \\
Aroma & 7.67 & 7.80 & 6.71 & 6.91 & 0,271 \\
Tekstur & 7.63 & 8.20 & 7.56 & 7.42 & 0,061 \\
Warna & 8.19 & 6.89 & 6.77 & 6.60 & $0.000^{*}$ \\
\hline
\end{tabular}

*Menn Whitney U Signifikan < 0,05 
Tabel 4. menggambarkan bahwa berdasarkan rasa, aroma, dan warna, ada perbedaan tingkat kesukaan panelis terhadap kue baruas yang diberi penambahan tepung daun kelor dengan kue yang tidak ditambahkan tepung $p$-value $<0,05$. Berdasarkan tekstur tidak ada perbedaan tingkat penerimaan panelis terhadap kue yang ditambahkan tepung daun kelor maupun tidak diberi tepung daun kelor $\mathrm{p}$ value $>0,05$. Berdasarkan rasa, aroma, tekstur maupun warna, tidak ada perbedaan tingkat penerimaan panelis terhadap 3 jenis kue baruas yang ditambahkan tepung daun kelor 5\%, 10\%, dan $15 \%$, p-value $>0,05$.

Tabel 4. Perbedaan Tingkat Kesukaan Panelis terhadap 4 Jenis Produk dengan Uji Hedonik

\begin{tabular}{ccccccccc}
\hline \multirow{2}{*}{$\begin{array}{c}\text { Jenis } \\
\text { Produk }\end{array}$} & \multicolumn{2}{c}{ Rasa } & \multicolumn{2}{c}{ Aroma } & \multicolumn{2}{c}{ Tekstur } & \multicolumn{2}{c}{ Warna } \\
\cline { 2 - 10 } & $\begin{array}{c}\text { Post-Neg. } \\
\text { Rank }\end{array}$ & $\begin{array}{c}\boldsymbol{\rho} \text { Value } \\
\text { Valut-Neg. }\end{array}$ & $\begin{array}{c}\text { Pank } \\
\text { Ralue }\end{array}$ & $\begin{array}{c}\text { Post-Neg. } \\
\text { Rank }\end{array}$ & $\begin{array}{c}\boldsymbol{\rho} \text { - } \\
\text { Value }\end{array}$ & $\begin{array}{c}\text { Post-Neg. } \\
\text { Rank }\end{array}$ & $\begin{array}{c}\boldsymbol{\rho} \text { Value } \\
\text { Value }\end{array}$ \\
\hline $0 \%-5 \%$ & $14-53$ & $0.000^{*}$ & $16-47$ & $0.035^{*}$ & $8-55$ & 0.215 & $32-35$ & $0,000^{*}$ \\
$0 \%-10 \%$ & $15-55$ & $0.000^{*}$ & $18-47$ & $0.017^{*}$ & $8-61$ & 0.450 & $30-28$ & $0,000^{*}$ \\
$0 \%-15 \%$ & $15-56$ & $0.000^{*}$ & $18-49$ & $0.031^{*}$ & $10-50$ & 0.546 & $33-17$ & $0,000^{*}$ \\
$5 \%-10 \%$ & $27-34$ & 0.235 & $18-29$ & 0.487 & $21-27$ & 0.416 & $26-23$ & 0,483 \\
$5 \%-15 \%$ & $30-36$ & 0.522 & $19-28$ & 0.788 & $25-30$ & 0.675 & $32-24$ & 0,641 \\
$10 \%-15 \%$ & $23-33$ & 0.538 & $20-20$ & 0.723 & $20-25$ & 0.491 & $22-24$ & 0,803 \\
\hline
\end{tabular}

*Kruskal Wallis Signifikan $\rho$-value $<0,05$

\section{PEMBAHASAN}

Penelitian menguji perbedaan kandungan zat gizi dan daya terima atau tingkat kesukaan kelompok panel terhadap produk (kue baruas) penambahan tepung daun kelor dengan konsentrasi $0 \%, 5 \%, 10 \%$, dan $15 \%$.

\section{Nilai Gizi Produk}

Daun kelor, tanaman multi gizi terutama zat gizi mikro (Fe, $\mathrm{Ca}$, dan $\mathrm{Zn})$, penggunaan tepung daun kelor pada pembuatan baruas diharapkan dapat menjadi solusi dalam mengatasi masalah stunting di wilayah ini. Penambahan tepung daun kelor dengan konsentrasi tinggi akan meningkatkan nilai gizi produk baik kualitas maupun kuantitas, namun setelah dilakukan penelitian dengan mengumpulkan pendapat masyarakat dari berbagai kelompok (ibu hamil, ibu menyusui, ibu balita, ibu rumah tangga, maupun wanita dewasa) didapatkan hasil bahwa penggunaan tepung daun kelor dengan konsentrasi tinggi kurang bahkan tidak diminati oleh masyarakat, hal yang sama telah dilaporkan pada beberapa penelitian sebelumnya.

Zat gizi terutama mineral $(\mathrm{Ca}, \mathrm{Fe}, \mathrm{Zn}$, dan protein) adalah zat gizi yang sangat dibutuhkan untuk pertumbuhan balita secara optimal. Penambahan tepung daun kelor pada produk kue diharapkan dapat meningkatkan konsentrasi zat gizi tersebut. Hasil penelitian atau pemeriksaan kandungan zat gizi yang terdapat dalam kue, baik yang ditambahkan tepung daun kelor maupun tidak ditambahkan, diperoleh hasil bahwa semakin tingi konsentrasi dan kelor, semakin tinggi pula kandungan zat gizi dalam kue tersebut.

Penelitian sebelumnya (Sidabutar, 2018) dilaporkan bahwa penambahan tepung daun kelor dengan konsentrasi tinggi meningkatkan kandungan zat gizi dalam produk, meskipun konsentrasi bahan lain diturunkan atau dikurangi, tetap kandungan zat gizi produk penambahan tepung dan kelor yang tinggi daripada produk dengan penambahan konsentrasi tepung daun kelor lebih rendah, meskipun konsentrasi bahan lain ditingkatkan.

Hasil yang diperoleh dari penelitian ini maupun penelitian sebelumnya, menunjukkan bahwa untuk meningkatkan nilai gizi produk terutama produk yang diperuntukkan untuk meningkatkan status gizi pada balita maupun kelompok masyarakat lainnya, tepung daun kelor merupakan pilihan yang tepat sebagai bahan subtitusi pada sebuah produk.

\section{Tingkat Kesukaan Panelis (Uji Hedonic)}

Daya terima/hedonik adalah cara pengujian dengan mengandalkan atau menggunakan panca indera manusia yang 
digunakan sebagai alat mengukur daya penerimaan terhadap suatu produk makanan. Nilai zat gizi dari suatu makanan adalah zat yang dibutuhkan oleh tubuh untuk pertumbuhan, perkembangan, pemeliharaan dan memperbaiki jaringan tubuh (Almatsier, 2003). Uji hedonik, dapat digunakan untuk menguji berbagai jenis produk menggunakan panca indra, secara umum tingkat kesukaan panelis terhadap prodak yang ditambahkan tepung daun kelor, rata-rata nilai tertinggi yang diberikan anggota panel adalah produk (kue baruas) dengan penambahan tepung daun kelor konsentrasi paling rendah (5\%), meskipun masih lebih rendah dari nilai yang diberikan tehadap produk tanpa penambahan tepung daun kelor.

Tingkat penerimaan para panel yang didapatkan pada penelitian ini sama dengan hasil yang didapatkan pada penelitian sebelumnya terhadap produk yang ditambahkan tepung daun kelor, antara lain penelitian yang telah dilakukan oleh (Moviana, 2015), (Hidayanti, 2017), (Rahmawati \& Adi, 2016), (Prabowo, 2016), dan (Risnawati, Fanny, Zakaria, \& Lestari, 2016), semuanya melaporkan bahwa tingkat penerimaan tertinggi produk dengan penambahan tepung daun kelor berdasarkan warna, rasa, tekstur dan aroma adalah penambahan daun kelor dengan konsentrasi paling rendah.

Kesamaan hasil yang diperoleh dari penelitian ini dengan beberapa penelitian yang telah dilakukan sebelumnya mengambarkan bahwa rasa khas yang terdapat pada daun kelor, dan rasa daun kelor yang pahit menjadi penyebab tingkat kesukaan panelis pada produk dengan penambahan tepung daun kelor konsentrasi tinggi lebih rendah, selain itu daun kelor juga mengandung zat anti gizi (saponin), yang menyebabkan rasa kurang enak ditenggorokan. Meskipun demikian, para peneliti tetap tertarik menggunakan daun kelor sebagai salah satu sumber zat gizi, terutama dalam mengatasi stunting.

Menyadari adanya rasa khas dari daun kelor, maka pada penelitian ini selain menguji tingkat kesukaan panelis terhadap produk, juga meminta pada anggota panel memberikan saran sesuai dengan nilai yang diberikan atau saran perbaikan agar produk menjadi lebih baik. Salah satu yang menjadi pertimbangan untuk perbaikan produk adalah untuk memperbaiki warna perlu ditambah pewarna alami, serta penambahan madu untuk memperbaiki rasa.

\section{KESIMPULAN DAN SARAN}

Kue baruas kelor dengan komposisi zat gizi $(\mathrm{Fe}, \mathrm{Ca}$, dan $\mathrm{Zn})$ tertinggi adalah kue dengan penambahan tepung daun kelor $15 \%$, dan paling rendah adalah kue tanpa penambahan tepung daun kelor. Ada perbedaan tingkat kesukaan panelis terhadap 4 jenis kue baruas berdasarkan rasa dan warna, tidak ada perbedaan tingkat kesukaan berdasarkan aroma dan tekstur. Produk (baruas penambahan tepung daun kelor) yang paling disukai oleh para anggota panel adalah kue dengan penambahan tepung daun kelor 5\%.

Untuk memperbaiki rasa dan aroma kue baruas beberapa saran dari para anggota panel perlu dipertimbangkan seperti penambahan BTM (zat pewarna alami, vanily, daun pandan, dan lain-lain). Uji laboratorium perlu dilakukan pengulangan pemeriksaan minimal 3 kali agar didapatkan perbandingan yang lebih akurat antara satu dengan yang lainnya. Pemilihan anggota panel untuk pengujian produk betulbetul diseleksi, tidak hanya melihat pengalaman, tetapi juga harus dapat memberikan saran perbaikan sesuai dengan apa yang dirasakan saat melakukan penilaian.

\section{DAFTAR PUSTAKA}

Adani, F. Y., \& Nindya, T. S. (2017). Perbedaan Asupan Energi, Protein, Zink, dan Perkembangan pada Balita Stunting dan non Stunting. Amerta Nutr, 46-51. https://doi.org/10.20473/amnt.v1.i2.2017. 46-51

Adenike, A. B., \& Engineering, B. (2014). The effects of drying on some nutrients moringa oliefera leaves, 15(2).

Almatsier, S. (2003). Prinsip Dasar Ilmu Gizi. Jakarta: Gramedia Pustaka Utama.

Ayustaningwarno, F. (2014). Teknologi Pangan; Teori Praktis dan Aplikasi. Yogyakarta: Graha Ilmu.

Hidayanti, H. (2017). Analisis Kadar Protein dan Daya Terima Biskuit Daun Kelor (Moringa oleifera) dengan Penambahan Tepung Ikan Bandeng (Chanos chanos). Repository Universitas Jember. Retrieved from

http://repository.unej.ac.id/handle/123456 789/82556

Moviana, R. (2015). Pembuatan Nugget 
Dengan Penambahan Daun Kelor Sebagai Makanan Alternatif Makanan Tinggi Zat Besi. Jurnal Kesehatan Umus Brebes, l(1).

Prabowo, A. R. (2016). Studi Penambahana Tepung Daun Kelor pada Produk Green Leaf Cake Terhadap Daya Terima Konsumen. Universitas Pendidikan Indonesia. Retrieved from http://repository.upi.edu/24073/2/S_MIK_ 1206671_Abstract.pdf

Rahmawati, P. S., \& Adi, A. C. (2016). Daya Terima dan Zat Gizi Permen Jeli dengan Penambahan Bubuk Dan Kelor (Moringa Oleifera). Media Gizi Indonesia, 11(1), 86-93. https://doi.org/http://dx.doi.org /10.20473/mgi.v11i1.86-93

Risnawati, Fanny, L., Zakaria, \& Lestari, R. S. (2016). Daya Terima Bolu Cukke dengan
Penambahan Tepung Daun Kelor (Moringa Oleifera). Poltekkes Kemenkes Makassar.

Salim, A., \& Hasyim, M. (2016). Perbedaan kandungan Zat Gizi Daun Kelor Berdasarkan Umur Daun dan Metode Pengeringan yang berbeda. Poltekkes Kemenkes Mamuju.

Sari, E. M., Juffrie, M., Nurani, N., \& Sitaresmi, M. N. (2016). Asupan protein , kalsium dan fosfor pada anak stunting dan tidak stunting usia 24-59 bulan. Jurnal Gizi Klinik Indonesia, 12(4), 152-159.

Sidabutar, L. M. (2018). Analisa Kandungan Gizi dan Daya Terima Crackers dengan Pemanfaatan Tepung Daun Kelor dan Tepung Ikan Lele. Repositori Institusi, USU. 